\title{
Nineteenth-Century Sentimental and Popular Trends and their Transformation in Fin-de-siècle Latvian Literature ${ }^{1}$
}

\author{
BENEDIKTS KALNAČS
}

PAULS DAIJA

\begin{abstract}
In this paper, the role of popular culture in fin-de-siècle Latvian literature has been explored by analysing the mid-nineteenth century Latvian translation of Christoph Schmid's novel Genoveva (1846) by Ansis Leitāns, and unfinished drama Genoveva (1908) by Rūdolfs Blaumanis. While the first version of the Genoveva story was created according to the patterns of popular literature and played a significant role in the development of the Latvian reading public, the author of the second version attempted to turn the plot of popular fiction into a work of elite literature, elaborating the issue of female agency and adding psychological ambiguity to the plot. The mixture of popular melodramatic imagination and modernist themes, as observed in Blaumanis's work, provides a deeper insight into fin-de-siècle literary techniques by turning attention to the conscious use of different literary styles and narrative levels and illuminating interactions between popular and elite culture. By comparing both works and interpreting their aesthetic innovations in terms of the relationship between idealism, realism and modernism, this paper traces the ways in which fin-de-siècle Latvian literature appropriated and reworked models of popular culture and developed new aesthetic insights by merging elements of low and high culture.
\end{abstract}

Keywords: popular culture; Latvian literature; melodramatic imagination; idealism; Rūdolfs Blaumanis

\section{Introduction}

This paper proposes to discuss in what ways the rise of modern Latvian literature in the second half of the nineteenth century has been shaped by

1 Research was prepared in the framework of the project "Empowering knowledge society: interdisciplinary perspectives on public involvement in the production of digital cultural heritage" (No.: 1.1.1.1/16/A/040) supported by EU ERDF. 
popular culture. It attempts to demonstrate that the role of popular culture in the formative process of Latvian society has been much more complex and profound than previous research considered it to be. Therefore, it is important to trace the history of the uses of popular culture in this process. In order to specify some crucial aspects of this development the paper is subdivided into three parts. First, the important role popular culture played in the formation period of Latvian civic society in the early and mid-nineteenth century, the time span more often defined by the first attempts to create a distinctive Latvian elite culture, is scrutinized. Second, the discussion shows how later, and especially during the fin-de-siècle, newly born national literature made an innovative use of earlier (mostly translated or adapted but well-known and widely read) texts which traditionally are attributed to popular literature. Third, contemporary theoretical discourse is brought to bear, pointing toward internal links between nineteenth-century idealism, realism, and modernism, in order to demonstrate the disappearance of clear cut borders between the respective trends due to the changing functions and uses of popular culture. In our case study we approach two different versions of the story of Genoveva, introduced into Latvian letters by Ansis Leitāns (1815-1874), one of the first native writers, in 1846, and given a new interpretation by Rūdolfs Blaumanis (1863-1908), a representative of realism and modernism in Latvian literature, in 1908, about half a century later. In addition, even if the focus of this investigation is on a literary paradigm, it suggests that the conclusions drawn deserve broader application in the study of popular culture more generally.

\section{Popular and elite culture: mid-nineteenth century}

The starting point is provided by a brief discussion of the $1840 \mathrm{~s}$ and $1850 \mathrm{~s}$, two decades marked by crucial changes in Latvian society, both in terms of the growing popularity of secular literature as well as the rise of a new generation of educated Latvians.

In the mid-nineteenth century the perception of reading among Latvians changed on a revolutionary scale. Most importantly, reading as a part of religious experience or utilitarian pastime gave way to a new concept of reading as consisting to a considerable extent of entertainment and pleasure. This was a part of a larger process that was characterized by the so-called revolution in reading. Its origins in other European societies can be traced back to the rise of the middle class in the seventeenth and especially in the eighteenth century. The history of Latvian civic society is inextricably linked to the German Enlightenment, and one of the most characteristic examples 
KALNAČS, DAIJA

in German literature where the new concept of reading comes to the fore was Johann Wolfgang Goethe's novel, The Sorrows of Young Werther (Die Leiden des jungen Werther, 1774). The extreme popularity of this emotionally charged text demonstrates the changing demands of the reading public which was by then more clearly interested in the excitement provided by works of art.

Another channel through which the trends in popular culture became more widespread was linked to the impact of the eighteenth-century popular enlightenment which was influential in German speaking territories and strongly resonated in Latvia. The representatives of the popular enlightenment were especially active in bringing forward the rational aspects of reading and wanted to provide their audiences with a sound basis of secular knowledge alongside religious experience. Thus there developed a characteristic blend of religious, secular, and fictional aspects of literature consumption which influenced the reading public and even initiated discussions about the value of reading itself and habits in general.

The described shift which coincided with the steady expansion of popular literature occurred simultaneously with the rise of an educated middle class. The attempts of young intellectuals at creating elite culture, which became especially manifest during the 1850 s, are noticeable in all parts of EastCentral Europe where the nineteenth century was strongly marked by the rise of nationalism. In the local Latvian context, the activities of the so-called movement of Young Latvians clearly included an effort to move away from the dominant tradition of Baltic German writing in the Latvian language, which in the middle of the nineteenth century predominantly relied on the sentimental and didactic patterns of the popular enlightenment. The strategic orientation of Young Latvians toward separation of elite and popular culture, and preference for the former, might be seen as a strong ideological message in regard to the appearance of a newly educated group of Latvians ready to speak in the name of the social as well as cultural aspirations of their nation. As Ivars Ijabs puts it, "they started to develop their own anti-German nationalism, which, on the one hand, often imitated German models, but on the other - challenged the supposed universalism of German culture. These attempts to build a Germantype high culture on the basis of an "inferior", colonized culture provoked loud complaints about hybridity and harmfulness, voiced by Baltic Germans, who increasingly asserted their colonizer identity and cultural superiority”. (Ijabs 2013: 90)

In practice, however, things turned out to be much more complicated, and the new elitist literature was not quite able to break with the popularity and even omnipresence of sentimental patterns. Subtle analysis provided by Maria Todorova with regard to the nineteenth-century Balkans demonstrates with 
remarkable clarity that, on the one hand, the nationalist movements consciously mobilized themselves in the realm of high culture, thus attempting to create a break from the Ottoman empire, while "[a]t the same time, on the level of popular culture and everyday life, the Ottoman legacy proved much more persistent." (Todorova 2009: 178-180) We face a similar situation in the Latvian context where in the middle of the nineteenth century the social and educational basis for implementing elite culture was still insufficient, and the attempts to modernize everyday life by the rising Latvian middle class depended on Baltic German examples.

In the process of self-evaluation the images created by popular culture throughout the nineteenth century arguably provided important tools for an interactive dialogue between the author and his (or, occasionally, her) audience. This observation creates an alternative viewpoint to the often promoted perception of mass culture as mostly "the threat of losing oneself in dreams and delusions and of merely consuming rather than producing". (Huyssen 1986: 50) Popular patterns were especially widely applied in the work of an earlier generation of authors usually called 'old-Latvians' in Latvian literary history who often used German literary models. In fact, the passive role traditionally ascribed to popular forms of art was often cleverly revised by the representatives of both 'old' and, on certain occasions, 'young' Latvians in the name of social progress and, somewhat later, national mobilization. In the context of this investigation, these commonalities point toward exciting processes already initiated by 'old' Latvians, who had not received the same education as their younger compatriots, but who still worked reasonably hard with the tools at their disposal, transferring the knowledge they had to their readership and gradually even showing more interest in translating elite works of world literature. (Apīnis, Silabriede 1987)

In this context, the subversive potential of popular culture has to be taken into serious account. According to a contemporary theorist, "[p]opular culture is made by subordinated peoples in their own interests out of resources that also, contradictorily, serve the economic interests of the dominant. Popular culture is made from within and below, not imposed from without or above as mass cultural theorists would have it. There is always an element of popular culture that lies outside social control, that escapes or opposes hegemonic forces." (Fiske 2006: 119) The most important achievement of mid-nineteenth century Latvian authors was the liberation of literature from the dominant morally didactic frame. The generation of 'old-Latvians' made a decisive step toward introducing entertainment and pleasure principles as important components of the reading experience among the Latvian population, which in perspective gradually opened up the way for the reception of elite culture. 
KALNAČS, DAIJA

This section is rounded off by pointing toward an interesting case of the localised story, Genoveva by Ansis Leitāns, published in 1846. With its blend of strong emphasis on the moral aspects, sentimental affection and twisted plot, the story became one of the most popular and widely read nineteenth-century Latvian books and set the model for popular fiction in subsequent decades. It has been described as one of the first Latvian bestsellers. (Limane 1985: 144)

Based on Medieval Latin narrative, later transferred to other cultural milieus, in the seventeenth century the tale of Genoveva became part of the so-called 'Blue Library' intended for French popular audiences. Leitāns's use of an early nineteenth-century German source, a book written by Christoph Schmid, a German Catholic priest, was affected by the eighteenth-century interest in Robinsonade motifs, that is, "deserted island stories", inspired by the English author Daniel Defoe. The novel by Defoe, Robinson Crusoe (1719), was translated into Latvian in 1824 but it was adapted from a German source fitting the widespread pattern of localization.

Schmid's works were often translated into Latvian throughout the 1830 s and 1840 s, providing a mixture of didactic intentions and exemplary and advisable reading which hides deeper conflicts and points toward the importance of traditional values, often juxtaposing those with different moral challenges. Most of the localized translations were published in repeated editions, thus to a considerable extent contributing to the situation that the 1830s and 1840s were the last time period when translated fictional texts dominated the book market in Latvia. The 1850s already experienced a major shift in this regard with native authors becoming considerably more present on the literary scene, and there was a steady rise in the prominence of ethnic Latvian authors throughout the following decades. While the aesthetic ambitions of mid-nineteenth century popular fiction were rather modest, its role in creating a modern reading public was crucial, and there was a rapid expansion of readers after the publication of Genoveva. (Johansons 1953: 65)

As the enlightenment era fascination with topics of wild nature, savagery, civilization, and technological and spiritual progress began to lose their overall appeal by the mid- nineteenth century, the way of narrating the story changed as well. The popularity of Genoveva, however, stands out in the dominating stream of popular literature of the first half of nineteenth century. It was reprinted three times in Latvian $(1845,1848,1867)$, and one of these editions was supplemented by a notice, stating that it was better to acquire the book and not only borrow it from other readers, thus pointing to this sort of widespread practice and to the popularity of the novel. (Limane 1985: 142-145)

The popularity of the Genoveva story might be explained not only by the key motifs of Robinsonade, but also by Leitāns's interest in melodramatic 
Nineteenth-Century Sentimental and Popular Trends and their Transformation

imagination and the development of a female character that fits into the theoretical context of femininity as one of the markers of popular literature. In this perspective, femininity has also been linked to the issue of expanded readership, a substantial part of it being made up of women by the mid-nineteenth century. (Watt 2001: 43-45) It is therefore interesting that Leitāns explicitly points toward the ordering aspect of the story, when in the introduction he encourages male readers to give this book to their wives, with a suggestion later also to share it with their daughters and maids. (Leitāns 1980: 49-50) At the same time Leitāns is to a certain extent innovative in his representation of a new type of woman in Genoveva, aptly described by literary historian Aleksejs Apinis as a strong, enterprising, practical and courageous female character. (Apinis 2000: 158) Genoveva refuses to remain simply an object, a place in the traditional plot from the narrative point of view; rather, she demonstrates her own agency through not passively submitting to external pressures, but actively striving for her own survival as well as that of her child during the forced exile. The final reunion with her husband is only made possible through the self-conscious display of her own will. In its strong emphasis on moral and human perfection, the novel corresponds to the "fundamental aims of aesthetic idealism: to uplift, ennoble, and transform humanity by filling us with a sense of the ideal". (Moi 2006: 87)

In the second half of the nineteenth century, which coincided with the development of Latvian elite literature, this blend of idealism and melodramatic imagination maintained its appeal to a wide reading public; however, by the end of the nineteenth century it was already considered worthless among the educated elites. Despite the elitist rejection of popular literature, it remained a rich depositary of beloved and recognizable imagery, which could be recycled and enriched with new meanings in elite literature.

The following discussion will demonstrate how an important intertextual link was established by a conscious appropriation of the same story by the elite culture of the fin-de-siècle for substantially different purposes.

\section{Elite and popular culture during the fin-de-siècle}

The 1890s may be regarded as the period of coming-of-age for Latvian culture, manifest in the exponentially activated reception of a wide range of literary sources and, even more remarkably, the first major aesthetic achievements comparable to developments on a European scale. The process of change is characteristically revealed through a mixture of literary styles and narrative levels, which corresponds to the intensity of aesthetic experiments. Different 
KALNAČS, DAIJA

styles of thought that have been discussed in the context of this process of attempting to adapt to the growing demands of the reading public include reverential, critical, individual, and analytical style in literary production. (Plakans 1969)

At the same time, literary criticism has repeatedly pointed out that European elite literature throughout the nineteenth century constantly used very diverse stylistic levels, including elements of popular culture such as the so-called melodramatic imagination. A major early example of this kind of scholarship was provided by Peter Brooks's 1976 book, The Melodramatic Imagination, where Brooks was keen to detect and discuss melodramatic elements which already form a substantial part of the literary work of such important nineteenth-century novelists as Balzac and Henry James. On the level of particular episodes in their texts, Brooks especially noted the necessity of the expression of basic feelings of human passion, "which represents a victory over repression, a climactic moment at which the characters are able to confront one another with full expressivity, to fix in large gestures the meaning of their relations and existence". (Brooks 1995: 4)

This approach also meant a response to readers' expectations. As library accounts of reading matter and book demand in Latvia testify, the majority of readers during the turn of the century still preferred translated pulp fiction.

While early modernist literature during the late nineteenth century generally tends toward making the expression of character subjectivity more inwardlooking, the intensity of feelings is clearly related to the modes of representation described above, and occasionally they are also used in a similar manner. It is important to note that, contrary to the mid-nineteenth century elitist writers of the so-called Young Latvian movement, modernist authors at the turn of the century tended not to detach from popular trends, but were becoming more aware of the possibilities provided by these patterns, and therefore tried to recycle popular imagery, topics, and plots in their work. Thus, even while the plot complications provided by mid-nineteenth century pulp fiction within the next decades were already considered of minor importance, at the same time it was possible to make a conscious recycling, which was based on the widespread popularity of the mentioned texts, and especially the Genoveva story.

The following discussion focusses on one example of this trend, the posthumously (1908) published play Genoveva by Rūdolfs Blaumanis, that provides an obvious link to the publication by Leitāns discussed earlier.

The impact of popular literature in Blaumanis's drama is established both on the level of plot and aesthetics. The relationship between Genoveva, her husband, and her supervisor Golo who is left to take charge of her while the landlord is going to war, is revealed through passionate soliloquies of the main 
characters, since the play is written in verse. It remained unfinished therefore the general impression is created by short scenes which rely on an early point in the narrative, linked to the husband's departure. While seemingly following the traditional story line, Blaumanis makes conscious use of meta-theatrical elements as well as important and innovative details such as orientalising the passion of Golo through the explicit connection of his ferocious character and melodramatic outbursts being connected to Golo's semi-Moorish roots. This corresponds to the exoticism of the eighth century setting of the original tale, as well as to fin-de-siècle interest in oriental motifs, which was remarkably manifest on both the popular and the elite level.

While exploiting the recognizable elements in the plot, character representation in Blaumanis's play is made much more complex, when compared to the overtly melodramatic 'beauty and villain' model in Leitāns's story. Genoveva acquires substantially more agency and internal passion through the subtle portrayal of her own desires, only partially fulfilled in her marriage, which she struggles to keep intact while at the same time she is fascinated by Golo. Even though the play remains unfinished, the author does not intend to allow for reconciliation on the narrative level, his main focus being the complexity of the unconscious life of the mind. Thus what is usually considered realist art in the discussion of Blaumanis's drama and prose appears on a closer inspection of this particular text to be a highly reflective modernist achievement, combining the representation of an intense passion with subtle psychological insight.

What is documented here is, first, a continuation of the patterns of popular literature both in terms of the plot and character portrayal which includes elements of excess; second, a meta-theatrical awareness of the author, expressed in his aim of creating elite literature, while also making deliberate use of the register of the melodramatic imagination.

With this in mind the third and final part of this paper discusses the complex relations between idealism, realism, and modernism, taking into account the role of popular culture in the potential re-evaluation of nineteenth-century literary history.

\section{Idealism, realism, modernism}

It is important to observe a fundamental change in attitude toward modernism in recent theoretical studies, which make this concept much more inclusive than in most of earlier research. In her ground-breaking study regarding the place of Henrik Ibsen in the history of literature and theatre, Toril Moi sharply attacks the so-called ideology of modernism, which narrows this concept down to a 
KALNAČS, DAIJA

specific set of twentieth-century high modernist texts and "produces formalist approaches to aesthetic works". (Moi 2006: 20) Such interpretations, according to Moi's opinion, exclude from the modernist context a number of nineteenthcentury literary creations with subversive social and aesthetic potential provided specifically by deep insights into character psychology.

In the narrowed interpretation of the concept of modernism, the importance of the representation of material conditions of everyday life, "in which various political, economic and social problems currently at issue might be explored and mediated" (Miller 2013: 9), is not sufficiently taken into account. Recent cultural materialist studies, however, convincingly demonstrate that visible signs of reality in nineteenth-century literature may also provide a surface which 'stands in' for the complex workings of the subconscious mind, an uncontested field of modernist inquiry.

The relationship between the categories of idealism, realism and modernism, as discussed by Moi, might also help explain the role of popular culture in nineteenth-century literature. For Moi, there still exists a separation, because "the end of idealism is the birth of modernism". (Moi 2006: 4) If, however, we add the missing binder of popular culture, we get a complex field of representation that moves beyond forceful Manichean divisions such as idealism vs modernism, or the more traditional juxtaposition of realism and modernism. The constant presence of popular culture in elite art, manifest throughout the nineteenth century, helps to substantiate the meta-literary (or, for that matter, the meta-theatrical) approach, characteristic of the fin-de-siecle, with authors consciously making use of the stylistic means of popular culture at their disposal in order to create elite works of art.

Blaumanis's play provides a characteristic case where modernist reflexivity and psychological insight is substantially enriched by the planned use of traditional patterns and aesthetic means of popular culture. The blend of idealism, realism, and early modernism points toward a complex representation of modernity, involving the whole spectrum between the deep immersion of Blaumanis's characters in their spiritual experience, and their outward specularity, requiring reflection from readers and/or spectators, and made obvious by the intended use of the melodramatic imagination and excess in particular scenes.

The stylistic approach of the writer thus demonstrates features characteristic of the fin-de-siecle period more generally, with the focal point being the inclusiveness of aesthetic strategies. These strategies incorporate traditional plots and other devices of popular literature, stretching back for at least half a century, into challenging insights of the experience of modern life. This corresponds to the apt remark by Andreas Huyssen, that "despite its undeniable 
Nineteenth-Century Sentimental and Popular Trends and their Transformation

adversary stance toward bourgeois society, the modernist aesthetic and its rigorous work ethic [..] seem in some fundamental way to be located also on the side of that society's reality principle, rather than on that of the pleasure principle." (Huyssen 1986: 50) The terms introduced in this quote and their context also point toward the subversive potential of popular culture within nineteenth-century art.

In conclusion, a brief note confirming what has been said above can be added, because it also strengthens the link between the two texts, discussed in this paper. In a recent monograph, Meredith Miller points out that "the female figure exemplifies this problem of modernity for male writers. [..] Gender is the means through which modernity articulates itself as a problem of agency because the material conditions of this epoch lend themselves to its expression as such." (Miller 2013: 13)

In this regard, the story of Genoveva is rather examplary. In its two different $19^{\text {th }}$ and early $20^{\text {th }}$ century representations of female character Blaumanis's text brings together a wide-ranging experience of idealism, realism, and the birth of modernism; this thorough blend paradoxically enough is orchestrated by the use of the means of popular culture.

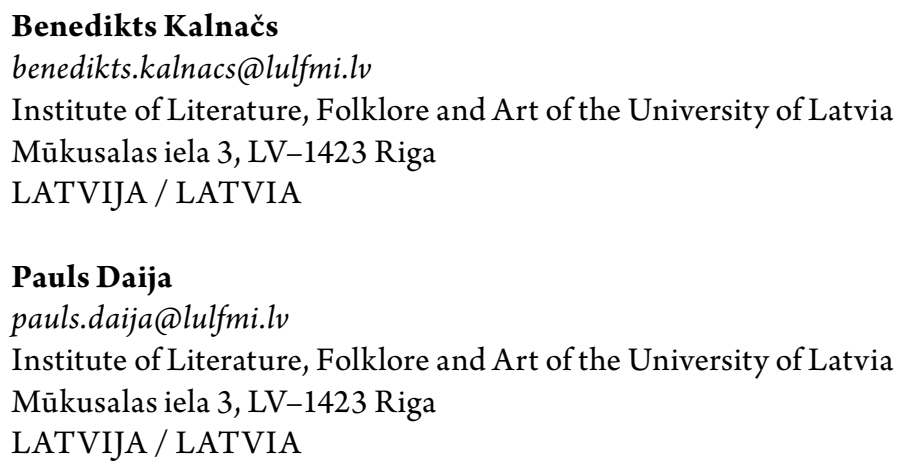

\section{Bibliography}

Apīnis, A. 2000. Soḷi senākās latviešu grāmatniecības un kultūras takās. Rīga: Preses nams.

Apīnis, A., I. Silabriede. 1987. Cittautu dzīves tēlojums tulkotajos stāstos. - I. Klekere, ed., Bibliotēku zinātnes aspekti. Grāmata latviešu sabiedrībā. 1856-1870. Rīga: Avots, $38-52$.

Blaumanis, R. 1958. Genoveva. - R. Blaumanis, Kopoti raksti, 5.sēj. Rìga: LVI, 341-399.

Brooks, P. 1995. The Melodramatic Imagination: Balzac, Henry James, Melodrama, and the Mode of Excess. New Haven and London: Yale University Press. 
KALNAČS, DAIJA

Fiske, J. 2006. Understanding Popular Culture. - H. E. Hinds, Jr., M. F. Motz, A. M. S. Nelson, eds., Popular Culture Theory and Methodology: A Basic Introduction. Madison: The University of Wisconsin Press, 118-126.

Huyssen, A. 1987. After the Great Divide: Modernism, Mass Culture, Postmodernism. Bloomington: Indiana University Press.

Ijabs, I. 2013. Another Baltic Postcolonialism: Young Latvians, Baltic Germans, and the Emergence of Latvian National Movement. - Nationalities Papers: The Journal of Nationalism and Ethnicity, 42(1), 88-107.

Johansons, A. 1953. Latviešu literatūras vēsture. Stokholma: Trīs zvaigznes.

Leitāns, A. 1980. Autobiogrāfija. Grāfa lielmāte Genoveva. Rīga: Liesma.

Limane, L. 1985. Robinsoniāde un stāsts par Genovevu latviešu grāmatniecībā. K. Arājs, ed., Grāmatas un grāmatnieki. Rīga: Zinātne, 138-145.

Miller, M. 2013. Feminine Subjects in Masculine Fiction: Modernity, Will and Desire, 1870-1910. Basingstoke: Palgrave Macmillan.

Moi, T. 2006. Henrik Ibsen and the Birth of Modernism: Art, Theater, Philosophy. Oxford: Oxford University Press.

Plakans, A. 1969. The National Awakening in Latvia 1850-1900. A thesis presented to the Department of History in partial fulfillment of the requirements for the degree of Doctor of Philosophy in the subject of History. Cambridge, Massachusetts: Harvard University. [Manuscript.]

Todorova, M. 2009. Imagining the Balkans. Oxford: Oxford University Press.

Watt, I. 2001. The Rise of the Novel: Studies in Defoe, Richardson and Fielding. Berkeley, Los Angeles: University of California Press. 